\title{
Practical Research on Creative Graffiti for Children
}

\author{
Xu Li \\ Department of Fine Arts, Chongqing University of Education, Chongqing 400067, China \\ 470428878@qq.com
}

Keywords: Child graffiti; Culture; Creativity; Creative idea; Creativity

\begin{abstract}
Children's graffiti express their inner world as an instinctive expression of behavior, a specific language symbols, and a creation of culture and art. Creative graffiti could stimulate children's latent consciousness and train children's abilities. It is an important direction of practical research on creative graffiti for developing children's physical and mental to provide a good mental space and hardware environment for children's graffiti.
\end{abstract}

\section{Significance of Graffiti in Children's Art Education}

Graffiti is one of the ways of artistic expression, which is also the main way for children to express their inner world. Two to three-year old is graffiti period, during which children instinctively impulses would began scribbling on paper. Children's performance in a variety of graffiti activities in the free and unfettered, which reveals the real feelings and is a natural way of expression. Therefore, graffiti plays an important role in the education of children's art. The education of children's art begins with graffiti, and graffiti education is the starting point of children's graffiti behavior. It is of great significance for the future education extension to pay attention to the art education of children in this period.

\section{Educational Value of Creative Graffiti for Children}

Graffiti is very strong in cultivating children's imagination and could further explore their creative abilities through the subconscious, which would affect one's habits of thinking and the development of life in the future. During this period, we should create a good graffiti environment in children's graffiti practice, actively stimulate and guide graffiti training, and then try to interpret their graffiti works with them. In such an environment, the graffiti thinking brought by the action and development potential would be fully developed, in which children would receive considerable satisfaction from the process and also emphasize their value unconsciously [1].

\section{Practical Education of Creative Graffiti for Children}

\section{Cultivation of Children's Creativity}

Aristotle once pointed out: "imagination is the source of all creative activities such as discovery and invention" [2]. Innovation is inseparable from imagination, and without imagination, there is no creation. Children's graffiti has a unique artistic charm, and is well received by artists and even art masters. Some people even compare children's paintings with those of art masters. In fact, the so-called "artistic charm and creativity" mostly refers to children's graffiti phenomenon, the children in the graffiti process unaware of their most primitive creativity dominates their graffiti art because of the cognitive level of psychological cognition. Over three-year old children's painting is emerged as a kind of language symbol; at this time, with strong curiosity and imagination, they imagine something that adult couldn't image, which is one of embodiments of children's interest. Therefore, the cultivation of children's creative thinking ability could be released through the process of child graffiti to stimulate their unconscious imagination. It shouldn't adopt the traditional indoctrination mode of education to bound children's thinking, which couldn't develop children's creativity. 


\section{Teaching Methods of Children's Graffiti Painting}

Graffiti in children's art is characterized by spontaneity, randomness and difference. Children's graffiti is "neither a landscape nor a deliberate abstract painting, nor is it a copy of any painting". Even for children painting theme in the classroom, children would "paint shamelessly and carefully in a happy and excited mood. They paint them in bright colors according to our requirements and paint the whole picture in full color". Children paint image is not accurate. "Even so, we don't see a dejected child because he does not draw a particular object" [3].

Children's graffiti is rich in original, accidental and changeable factors, which breeds infinite potential. As children's art has its own characteristics, any adult standards in an attempt to go beyond this particular stage of children's graffiti practice would be spoil things by excessive enthusiasm for children, which would damage artistic talent. For a child to express their ideas, it is important on performance, rather than the content [4]. The graffiti is the true self-expression method, children show love and not love about the world around him to express his feeling while graffiti, which express their feeling, visual and tactile. As for painting skills, it is not suitable for instilling in children's paintings. Such works lack the inner spirit and most direct \& sincere feelings expressing. Even if a child is forced to draw a "real" work, he could not understand and accept the object of his paintings. This method of teaching beyond the present stage of children would lead to the wrong direction for children's future mental growth. As a result, it should intervene as little as possible about the child's development during the graffiti stage.

\section{Redefining Children's Graffiti}

Children's graffiti painting is different from the adults. Children's art is reflected in their exploration for infinite life and world, experience and needs of unknown thing, as well as performance and passion in the process of creating rather than the result they are drawn. Standing in the children's point of view to appreciate the beautiful process is the significance and spirit of children's graffiti expression.

\section{Guideline Method of Children's Graffiti Art}

Any kind of guidance method could not immediately train children or stimulate children's potential. It is necessary to train children to face their more powerful emotional performance. [5]However, no matter what kind of motivation teachers adopt in creative education, they are mainly based on three factors: First, the teacher's own accomplishment, that is, the teacher's own creativity, and adaptability, which are very important to the surrounding environment; Second, teachers could shift their minds and imagine how children's roles in the graffiti world and the development of their storylines appear in graffiti. Third, fully understand objects they teaches that is helpful to fully understand children's personality characteristics to guide children's graffiti.

\section{Teachers Express Themselves Through Self-Understanding}

The development of children's graffiti painting depends on the research and development of teacher input, and almost all self-cognition is beneficial in all social sciences. Self-understanding is the basis of graffiti painting education, and a medium of learning; if teachers do not understand the needs of children's graffiti painting development, they could not understand the needs of children's graffiti painting. Teachers should encourage young children to boldly imagine, actively express, and actively create, make use of the aesthetic art atmosphere in various forms of art education activities, so that children could make full use of graffiti art language.

\section{Teacher's Understanding on Children's Graffiti Teaching}

Every child is creative. Children make use of lines, graphics and colors to translate their experiences, impressions and emotions into art graffiti, and create novel and unique art works using with materials, tools and past experience. When the teachers see the children doodling, first of all, they should understand the individual needs of the child; in the teaching, the teacher should understand children's psychological and physiological needs when they understand the general needs of children's graffiti. Only in this way could we fully understand the needs of children's painting and develop the demand for individual graffiti in a comprehensive and effective way. 


\section{Improve Children's Appreciation Ability}

Art is a creative activity, for which children could express their feelings and understanding of their works in their own unique way of expression. For art education, we should follow the scientific, positive and initiative method to fully mobilize the children's art creation in art activities, so that children could display their feeling and desire in art. It could communicate with them by heart through observing children's behavior, experiencing children of the passions with childlike innocence. [6] We could understand the children's creative fun by understanding children's physical and mental development and artistic modeling features, and thinking and working with them together.

\section{References}

[1] D.M. Zeng and W. Xiong. The development and education of children's graffiti [J]. Today's education: contemporary preschool education. 2007.

[2] (USA) Lowenfeld, "creation and the growth of mind" [M], Hunan fine arts press, 1993 edition, page 87-92.

[3] L.Q. Yan, the image of children during the period of "art form." [J].experience "creative teaching, basic education forum, 2014.

[4] X.Y. Guo, W.S. Li and B.Q. Gao, children's creative study art education [J]."Silk Road", 2017 (9).

[5] L.M. Hou, When the children's early paintings Limin, and its influence on education [J]. preschool education research, 2006 (01)

[6] A.H. Song, art education research [J], creative painting and development of children's creativity, 2012 (2), 114-115. 